\title{
Anaerobic degradation of sorbic acid by sulfate-reducing and fermenting bacteria: pentanone- 2 and isopentanone- 2 as byproducts
}

\author{
Sylvia Schnell ${ }^{1}$, Christine Wondrak ${ }^{1}$, Günther Wahl ${ }^{2}$ \& Bernhard Schink ${ }^{1}$ \\ ${ }^{1}$ Lehrstuhl Mikrobiologie I, Eberhard-Karl-Universität, Auf der Morgenstelle 28, D-7400 Tübingen, \\ Germany; ${ }^{2}$ Medizinische Universitätsklinik, Abt. Innere Medizin IV, Klinische Chemie, D-7400 Tübingen, \\ Germany
}

Key words: anaerobic degradation, $\beta$-oxidation, decarboxylation, ketones, sorbic acid

\begin{abstract}
Strictly anaerobic bacteria were enriched and isolated from freshwater sediment sources in the presence and absence of sulfate with sorbic acid as sole source of carbon and energy. Strain WoSo1, a Gram-negative vibrioid sulfate-reducing bacterium which was assigned to the species Desulfoarculus (formerly Desulfovibrio) baarsii oxidized sorbic acid completely to $\mathrm{CO}_{2}$ with concomitant stoichiometric reduction of sulfate to sulfide. This strain also oxidized a wide variety of fatty acids and other organic compounds. A Gram-negative rod-shaped fermenting bacterium, strain AmSo1, fermented sorbic acid stoichiometrically to about equal amounts of acetate and butyrate. At concentrations higher than $10 \mathrm{mM}$, sorbic acid fermentation led to the production of pentanone-2 and isopentanone-2 (3-methyl-2-butanone) as byproducts. Strain AmSo1 fermented also crotonate and 3-hydroxybutyrate to acetate and butyrate, and hexoses to acetate, ethanol, hydrogen, and formate. The guanine-plus-cytosine content of the DNA was $41.8 \pm 1.0 \mathrm{~mol} \%$. Sorbic acid at concentrations higher than $5 \mathrm{mM}$ inhibited growth of this strain while strain WoSo1 tolerated sorbic acid up to $10 \mathrm{mM}$ concentration.
\end{abstract}

\section{Introduction}

Sorbic acid (hexa-2,4-dienoic acid) is present in many fruits, e.g. in rowanberries (Sorbus aucuparia) and strawberries (Bayer \& Walter 1988). Synthetical sorbic acid is used as antibacterial and antifungal food additive in cheese, yoghurt, and conserved meat. Enterobacteriaceae, staphylococci and pseudomonads are inhibited by sorbic acid at concentrations of $50-100 \mu \mathrm{g} / \mathrm{ml}$ (Russell \& Gould 1988). Like benzoic acid, sorbic acid affects the proton motive force and accelerates proton movement from the medium into the cytoplasm, as studies with Escherichia coli revealed (Salmond et al. 1984; Eklund 1985). Other effects were described for Clostridium sporogenes, which can basically be attributed to protonophoric activity as well: sorbic acid inhibited uptake of essential amino acids, decreased the rate of protein synthesis, altered the patterns of phosphorylated nucleotides (GTP and ppGpp) and caused drastic morphological changes at 50-200 mM concentrations (Ronning \& Frank 1987, 1989). In Bacillus subtilis, uptake of serine or a-amino-isobutyric acid is inhibited by sorbic acid (Freese et al. 1973), whereas yeasts are inhibited in phosphate uptake (Borst-Pauwels \& Jager 1969). Some enzymes of bacterial carbohydrate metabolism like enolase and lactic dehydrogenase are directly inhibited by sorbic acid; perhaps essential sulfhydryl groups of these enzymes are masked or 
oxidized by the conjugated double bonds of sorbic acid (Fulgraff 1989). Certain other bacteria such as lactic acid bacteria appear to be unaffected by sorbic acid.

Except for its toxicity, sorbic acid does not pose any basic problems to microbial degradation, especially in the presence of oxygen or nitrate as electron acceptor but no detailed studies on sorbic acid degradation have been published so far. In the present communication we report on degradation of sorbic acid by strictly anaerobic sulfate-reducing and fermenting bacteria.

\section{Materials and methods}

\section{Organisms and cultivation}

Enrichment cultures were inoculated with black sediment samples from two polluted freshwater creeks near Konstanz, Germany (Wollmatinger Graben) and near Tübingen, Germany (Ammerkanal), as well as with a marine sediment sample taken from Rio della Pergola, a canal in the city of Venice, Italy. Methanospirillum hungatei strain M1h was obtained from Prof. Dr. F. Widdel, München, Germany.

All procedures for cultivation were essentially as described by Widdel \& Pfennig (1981). The mineral medium for enrichment, isolation, and cultivation contained $30 \mathrm{mM}$ sodium bicarbonate buffer, $1 \mathrm{mM}$ sodium sulfide as reducing agent, the trace element solution SL 10 (Widdel et al. 1983) and a 7 vitamin solution (Widdel \& Pfennig 1981). Freshwater medium contained per liter $0.5 \mathrm{~g} \mathrm{NaCl}$ and $0.4 \mathrm{~g}$ $\mathrm{MgCl}_{2} \times 6 \mathrm{H}_{2} \mathrm{O}$, saltwater medium $20.0 \mathrm{~g}$ and $3.0 \mathrm{~g}$, respectively. The $\mathrm{pH}$ was $7.1-7.3$, and the incubation temperature $30^{\circ} \mathrm{C}$. For isolation of pure cultures, the agar shake dilution method was applied (Pfennig 1978). Gram staining was carried out after Magee et al. (1975).

\section{Enzyme measurements}

Carbon monoxide dehydrogenase (Diekert \& Thauer 1978) and 2-oxoglutarate synthase (Bran-
dis-Heep et al. 1983) were measured with methyl viologen as electron acceptor under strictly anoxic conditions with cell-free extracts prepared by French pressure treatment of fresh cell material (for details see Schnell \& Schink 1991). Protein was quantified after Bradford (1976).

\section{Fermentation product analysis}

Fatty acids and ketones were identified and quantified with a Vega 6000 gas chromatograph (Carlo Erba Strumentazione, Milano, Italy) equipped with a $2 \mathrm{~m} \times 2 \mathrm{~mm}$ glass column packed with $60 / 80$ Carbopak C/0.3\% Carbowax 20M/0.1\% $\mathrm{H}_{3} \mathrm{PO}_{4}$ (Supelco Inc., Bellefonte, PA, USA), injector and detector temperature $200^{\circ} \mathrm{C}$, temperature program $80-160^{\circ} \mathrm{C}$, carrier gas nitrogen at $40 \mathrm{ml} / \mathrm{min}$ (modified after Schink \& Pfennig 1982). Samples were acidified with formic acid ( $0.5 \mathrm{M}$ final concentration) prior to injection.

\section{HPLC-Analysis of sorbic acid}

Samples $(100 \mu \mathrm{l})$ were preserved by injection into $1 \mathrm{ml}$ glass vials containing $400 \mu \mathrm{l}$ of $0.1 \mathrm{M} \mathrm{H}_{3} \mathrm{PO}_{4}$, and stored at $-20^{\circ} \mathrm{C}$ prior to analysis. Samples were analyzed with a System Gold high-pressure liquid chromatograph (Beckman Instruments, München, Germany) on an Ultrasphere-ODS column $(4.6 \times 150 \mathrm{~mm})$, using a $50 \% 100 \mathrm{mM}$ ammonium phosphate $50 \%$ methanol sovent system $(\mathrm{pH}$ 2.6). Samples $(20 \mu \mathrm{l})$ were injected with a Spark Promis II autosampler (Beckman Instruments, München, Germany) and eluted at a flow rate of $1 \mathrm{ml} / \mathrm{min}$. Sorbic acid was detected in a variablewavelength detector (Beckman type 166) at $263 \mathrm{~nm}$. Data were analyzed by a computer program and quantified by comparison with external standards.

\section{Identification of pentanones by mass spectrometry}

Fermentation products in $10 \mathrm{ml}$ culture supernatant of strain AmSo1 were purified and concentrat- 
ed by solid phase extraction using C-18 Bond Elut column (ict Handels GmbH, Frankfurt). The columns were conditioned with $2 \times 0.5 \mathrm{ml}$ methanol and $2 \times 0.5 \mathrm{ml} \mathrm{H}_{2} \mathrm{O}$ and eluted with $2 \times 0.5 \mathrm{ml}$ methanol. Analysis was carried out on a gas chromatography mass spectrometry system (Hewlett Packard HP 5890/5971 A, electron ionization at $70 \mathrm{eV}$ ) equipped with a HP 1 column (dimethyl polysiloxane), $25 \mathrm{~m} \times 0.2 \mathrm{~mm} \times 0.33 \mu \mathrm{m}$ in size, column pressure $50 \mathrm{kPa}$. The temperature of the injector was $270^{\circ} \mathrm{C}$, the MS interface was kept at $280^{\circ} \mathrm{C}$ and the ion source at $170^{\circ} \mathrm{C}$.

\section{Analysis of DNA}

The guanine-plus-cytosine content of the DNA was determined by the thermal denaturation method according to DeLey (1970) after extraction as described by Marmur (1961).

\section{Chemicals}

All chemicals used were of analytical grade quality and obtained from Fluka, Neu Ulm, Merck, Darmstadt, and Sigma, München, Germany. $\mathrm{H}_{2}, \mathrm{~N}_{2}$ and $\mathrm{N}_{2} / \mathrm{CO}_{2}$ gas mixtures were obtained from Messer Griesheim, Ludwigshafen and $\mathrm{CO}$ from Linde, Unterschleißheim, Germany.

\section{Results}

Enrichment, isolation and morphology of sorbatedegrading anaerobes

Enrichment cultures with black anoxic mud from a ditch near Konstanz, Germany, in freshwater mineral medium containing $2 \mathrm{mM}$ sorbic acid and $20 \mathrm{mM}$ sulfate showed sulfide production within three weeks. After repeated transfers in the same medium, motile vibrioid bacteria dominated. These bacteria were isolated in two subsequent agar dilution series with $2 \mathrm{mM}$ sorbic acid and $20 \mathrm{mM}$ sulfate. Yellowish-brown, irregularly shaped colonies developed within four weeks and consisted of the motile vibrios. After subjection to a further agar dilution series, strain WoSo1 was isolated.

In enrichment cultures with saltwater medium inoculated with sediment of a canal in Venice, Italy, with $2 \mathrm{mM}$ sorbic acid and $20 \mathrm{mM}$ sulfate, a diverse bacterial population developed rather slowly. These cultures were not characterized any further. Enrichment cultures with sulfate-free freshwater medium inoculated with sediment from a polluted freshwater creek near Tübingen exhibited methane formation within 3 weeks of incubation. After two subsequent transfers, the predominant bacterial type, strain AmSo1, was isolated by agar shake dilutions.

Cells of strain WoSo1 were curved rods, $2-4 \mu \mathrm{m}$ long and $0.5 \mu \mathrm{m}$ in diameter (Fig. 1a). Cells were motile and rotated around the long cell axis both in young and old cultures. They stained Gram-negative; spores could not be detected.

Cells of strain AmSol were short straight rods, $0.6 \times 1.0-1.5 \mu \mathrm{m}$ in size, after growth with sorbic acid (Fig. 1b). Glucose-grown cells were wider $(0.8 \mu \mathrm{m})$ and up to $5 \mu \mathrm{m}$ long (Fig. 1c). Mutual checks were made by agar shake dilutions with both substrates to make sure that sorbate-grown and glucose-grown cells were bacteriologically identical. Cells stained Gram-negative and did not form spores.

Growth physiology and stoichiometry of substrate degradation by strain WoSo1

Strain WoSo1 grew only in freshwater medium. No growth occurred in brackish water medium or saltwater medium. The $\mathrm{pH}$ range of growth was $\mathrm{pH} 6.8$ to 7.6 , with an optimum at $\mathrm{pH} 7.2$. No growth was observed below $20^{\circ} \mathrm{C}$ or above $35^{\circ} \mathrm{C}$; best growth occurred at $28^{\circ} \mathrm{C}$.

Sorbic acid was oxidized completely to $\mathrm{CO}_{2}$ with concomitant reduction of sulfate to sulfide. No inhibition of growth (initial rates) was observed up to $10 \mathrm{mM}$ sorbic acid. Substrate-dependent growth and sulfide formation are shown in Fig. 2. In Table 1 , the stoichiometry of sorbic acid oxidation by strain WoSol is documented. The molar ratio of 

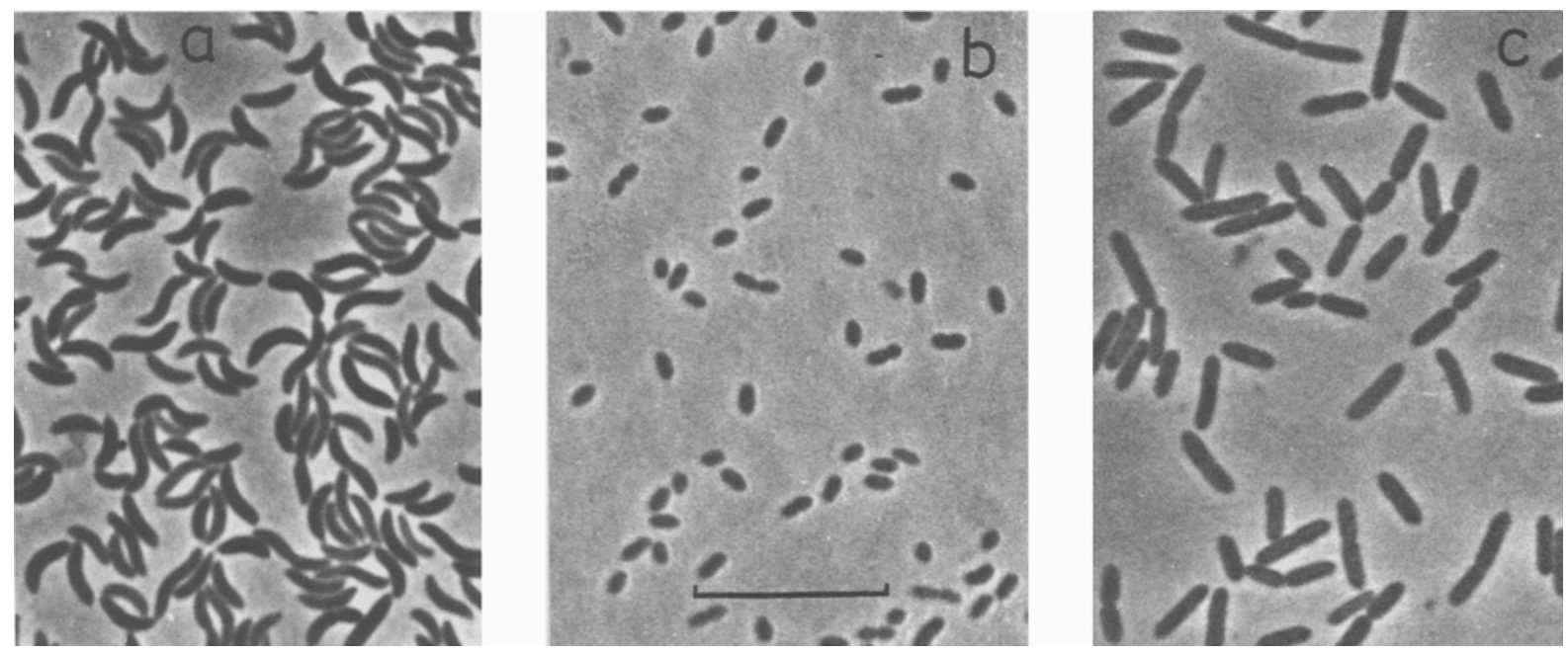

Fig. 1. Phase-contrast photomicrograph of the new isolates. (a) Strain WoSo1, grown with $2 \mathrm{mM}$ sorbic acid and $20 \mathrm{mM}$ sulfate. (b) Strain AmSo1, grown with $5 \mathrm{mM}$ sorbate. (c) Strain AmSo1, grown with $2 \mathrm{mM}$ glucose. Bar equals $10 \mu \mathrm{m}$ for all panels.

sorbic acid dissimilated over sulfide formed was 1 : 3.5. The growth yield determined was $39.7 \mathrm{~g}$ per mol sorbic acid, and the doubling time $55 \mathrm{~h}(\mu=$ $0.013 \mathrm{~h}^{-1}$ ) for growth with sorbic acid. Strain

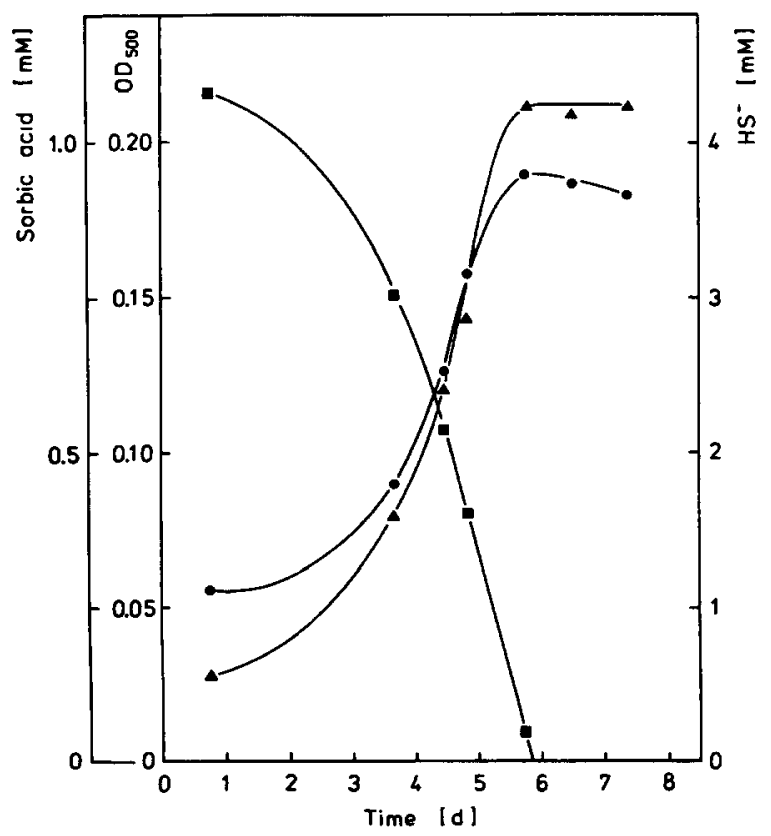

Fig. 2. Time course of sorbic acid degradation by strain WoSo1. (a) sorbic acid, (O) optical density, (A) sulfide.
WoSo1 grew also with fatty acids with chain lengths of $\mathrm{C}_{1}-\mathrm{C}_{8}$ and with the unsaturated fatty acids crotonate and trans-2-hexanoate. Further substrates supporting growth were pyruvate, lactate, and aliphatic alcohols. Dicarboxylic acids were not degraded (Table 1).

The pathway of acetate oxidation by strain

Table 1. Stoichiometry of sorbic acid oxidation by strain WoSo1.

\begin{tabular}{lc}
\hline Sorbic acid degraded [mmol] & 1.08 \\
Sulfide produced [mmol] & 3.68 \\
Net final OD $_{500}$ & 0.135 \\
Dry matter formed [mg] & 29.2 \\
Sorbic acid assimilated $[\mathrm{mmol}]$ & 0.17 \\
Sorbic acid dissimilated [mmol] & 0.91
\end{tabular}

a Substrate assimilated for cell matter synthesis was calculated by the following equation:

$\left.17 \mathrm{C}_{6} \mathrm{H}_{8} \mathrm{O}_{2}+10 \mathrm{CO}_{2}+30 \mathrm{H}_{2} \mathrm{O} \rightarrow 18<\mathrm{C}_{4} \mathrm{H}_{7} \mathrm{O}_{3}\right\rangle$

$5.95 \mathrm{mmol}$ sorbic acid is assimilated into $1 \mathrm{~g}$ of dry cell matter.

Other substrates supporting growth (mM concentrations in brackets): Formate (7), acetate (10), propionate (10), butyrate (5), valerate (5), caproate (4), heptanoate (1.5), caprylate (1), lactate (10), pyruvate (10), crotonate (5), trans-2-hexenoate (2), n-propanol (5), n-butanol (5).

Substrates not supporting growth: Maleinate (3), succinate (5), fumarate (5), malate (5), glutarate (3), adipate (2), pimelate (1), acrylate (5), ethanol (10), 1,3-propanediol (5). 
WoSo1 was studied by measurement of key enzymes in cell-free extracts. Carbon monoxide dehydrogenase was found at high activity $(11.5 \mu \mathrm{mol}$ $\mathrm{CO}$ per min and mg protein); 2-oxoglutarate synthase activity could not be detected with methyl viologen as electron acceptor.

Growth physiology and stoichiometry of substrate degradation by strain AmSol

Strain AmSo1 was strictly anaerobic, catalase and oxidase negative, and did not contain cytochromes as visualized in redox difference spectra of crude cell extracts. The guanine-plus-cytosine content of the DNA was $41.8 \pm 1.0 \mathrm{~mol} \%$.

Sorbate was fermented to about equal amounts of acetate and butyrate, and a small amount of a further product which was later identified as pentanone-2 (Fig. 3). The doubling time was $33 \mathrm{~h}(\mu=$ $0.021 \mathrm{~h}^{-1}$ ) during growth with sorbic acid. Other substrates supporting growth were 3-hydroxybutyrate and crotonate which were fermented to acetate and butyrate, with traces of acetone (Table 2 ). Fructose and glucose were fermented to acetate, ethanol, formate, and traces of hydrogen.

Two unknown byproducts of sorbic acid degra-

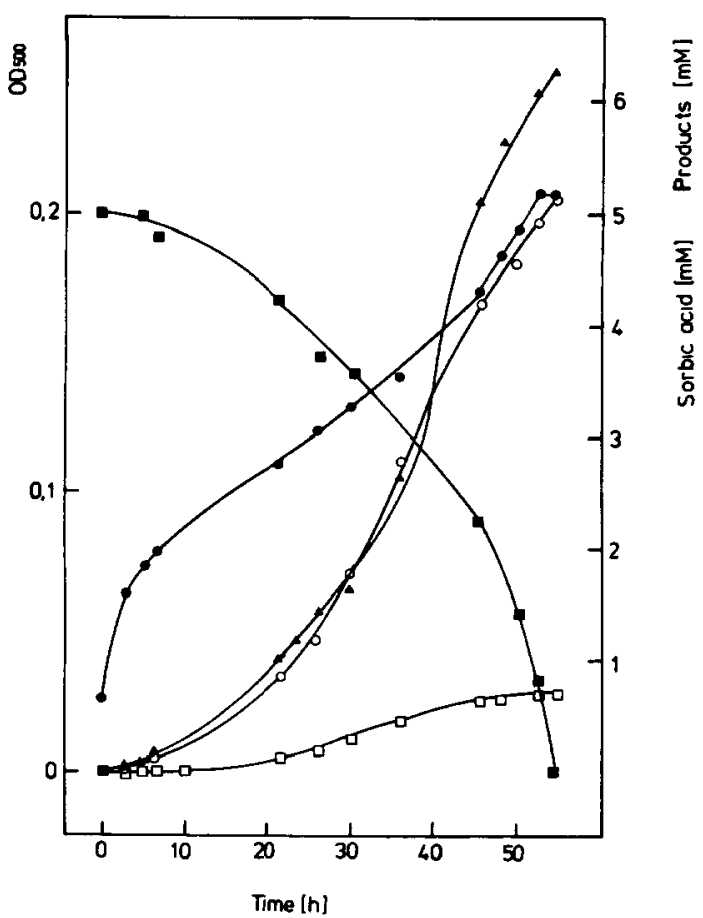

Fig. 3. Time course of sorbic acid degradation by strain AmSo1. $(\boldsymbol{D})$ sorbic acid, $(\boldsymbol{O})$ optical density, $(\boldsymbol{\Delta})$ acetic acid, $(O)$ butyric acid, ( $\square$ ) pentanone-2.

Table 2. Growth and stoichiometry of substrate degradation by strain AmSo1.

\begin{tabular}{|c|c|c|c|c|c|c|c|c|c|c|c|c|}
\hline \multirow[t]{2}{*}{ Substrate } & \multirow{2}{*}{$\begin{array}{l}\text { Concen- } \\
\text { tration } \\
(\mathrm{mM})\end{array}$} & \multirow{2}{*}{$\begin{array}{l}\text { net } \\
\mathrm{OD}_{500}\end{array}$} & \multirow{2}{*}{$\begin{array}{l}\text { Cell }^{\mathbf{a}} \\
\text { matter } \\
\text { formed } \\
(\mathrm{mg} / \mathrm{ml})\end{array}$} & \multirow{2}{*}{$\begin{array}{l}\text { Substrate } \\
\text { assimil. } \\
(\mathrm{mM})^{\mathbf{b}}\end{array}$} & \multicolumn{4}{|c|}{ Products formed (mM) } & \multirow[t]{2}{*}{$\mathrm{H}_{2}$} & \multirow[t]{2}{*}{ Formate } & \multirow{2}{*}{$\begin{array}{l}\text { Electron } \\
\text { balance } \\
(\%)\end{array}$} & \multirow{2}{*}{$\begin{array}{l}\text { Growth } \\
\text { yield } \\
(\mathrm{g} / \mathrm{mol})\end{array}$} \\
\hline & & & & & Acetate & Butyrate & $\begin{array}{l}\text { Penta- } \\
\text { none }\end{array}$ & Ethanol & & & & \\
\hline Sorbate & 4 & 0.117 & 30.7 & 0.18 & 4.34 & 3.38 & 0.02 & - & - & - & 96.2 & 8.6 \\
\hline $\begin{array}{l}\text { Sorbate } \\
\text { 3-Hydroxy- }\end{array}$ & 5 & 0.156 & 41.0 & 0.24 & 4.8 & 4.2 & 0.04 & - & - & - & 92.5 & 8.7 \\
\hline butyrate & 10 & 0.194 & 51.0 & 0.46 & 12.85 & 3.14 & $-c$ & 0.91 & 0.17 & - & 98.3 & 5.4 \\
\hline Crotonate & 5 & 0.134 & 35.3 & 0.32 & 5.28 & 1.57 & $-^{c}$ & 0.21 & 0.07 & - & 90.4 & 7.7 \\
\hline Glucose & 5 & 0.450 & 118.5 & 1.07 & 2.61 & - & - & 4.97 & 0.16 & 6.9 & 100.3 & 20.5 \\
\hline Fructose & 5 & 0.390 & 102.7 & 0.93 & 3.11 & - & - & 4.41 & 0.14 & 6.6 & 94.7 & 17.8 \\
\hline
\end{tabular}

Growth with acetoin was possible as well, however, growth was only very low and substrate degradation was incomplete.

${ }^{a}$ Cell dry matter formed was calculated via the experimentally determined conversion factor $0.1 \mathrm{OD}_{500}=26.3 \mathrm{mg}$ cell mass per liter.

${ }^{b}$ Substrate assimilation into cell material was calculated after the equation $17 \mathrm{C}_{6} \mathrm{H}_{8} \mathrm{O}_{2}+10 \mathrm{CO}_{2}+30 \mathrm{H}_{2} \mathrm{O} \rightarrow 28\left[\mathrm{C}_{4} \mathrm{H}_{7} \mathrm{O}_{3}\right]$.

c Small amounts of acetone $(<0.07 \mathrm{mM})$ were found as byproduct.

Substrates not supporting growth (mM concentrations in brackets): Methanol (10), ethanol (10), propanol (10), ethylene glycol (10), glycerol (10), 2,3-butanediol (10), formate (20), methoxyacetate (10), lactate (10), acrylate (2), malate (10), betaine (10), choline (10), arabinose (5), xylose (5), phloroglucinol (5), pyrogallol (5), $\mathrm{H}_{2} / \mathrm{CO}_{2}(80 \% / 20 \%)$. 

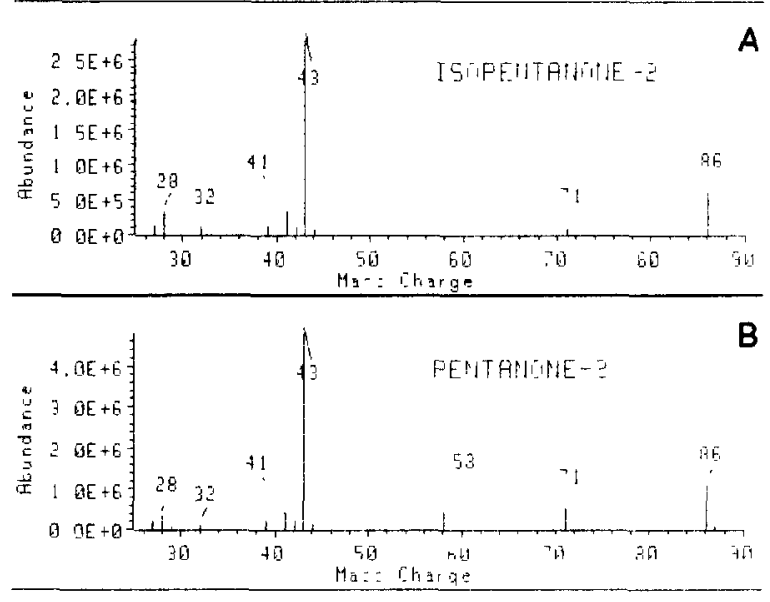

Fig. 4. Mass spectrometric fragmentation patterns of byproducts of sorbate fermentation by strain AmSo1. (A) Isopentanone-2 (3-methyl-2-butanone), (B) pentanone-2.

dation which showed up as a small and a large peak $\left(\mathrm{t}_{\mathrm{r}}\right.$ at $1.06 \mathrm{~min}$ and $\left.1.38 \mathrm{~min}\right)$ in gas chromatographic fatty acid analysis were identified by gas chromatography mass spectrometry. The fragmentation patterns (Fig. 4) were compatible with isopentanone- 2 and pentanone- 2 , respectively. Isopentanone- 2 made up less than $20 \%$ of total pentanone formed.

Strain AmSo1 exhibited substrate-dependent growth and product formation up to about $5 \mathrm{mM}$ sorbate; at higher concentrations, growth and substrate conversion were inhibited, and pentanone-2 accumulated up to $0.8 \mathrm{mM}$ concentration (Fig. 5). In mixed cultures of strain AmSo1 with Methanospirillum hungatei, $10 \mathrm{mM}$ butyrate was not oxidized during more than 2 months of incubation.

\section{Discussion}

\section{Anaerobic degradation of sorbate}

In the present publication, degradation of sorbate by strictly anaerobic bacteria was studied in detail for the first time. Two different types of anaerobes were found to degrade this substrate: a sulfatereducing bacterium oxidized it completely to $\mathrm{CO}_{2}$, according to the equation:

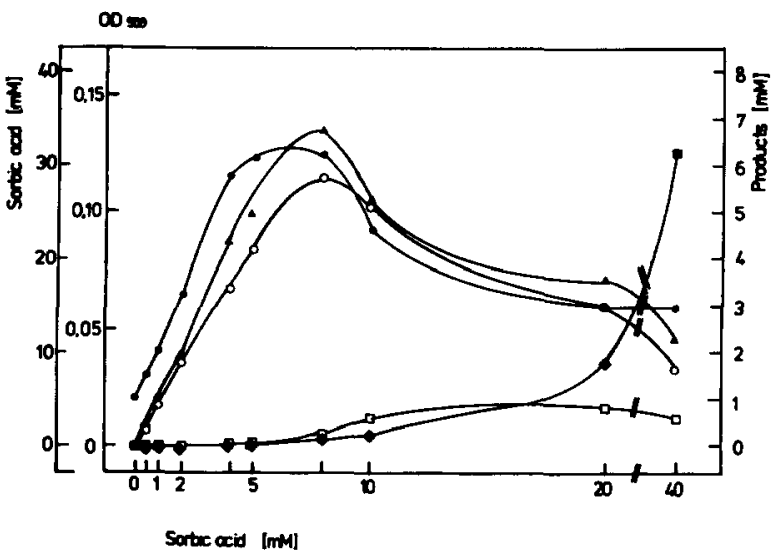

Fig. 5. Growth and product formation pattern by strain AmSo1 with increasing amounts of sorbate provided. ( $\square$ ) Sorbic acid, (O) optical density, ( $\Delta$ ) acetic acid, (O) butyric acid, $(\square)$ pentanone-2.

$$
\begin{aligned}
& 2 \mathrm{C}_{6} \mathrm{H}_{7} \mathrm{O}_{2}{ }^{-}+7 \mathrm{SO}_{4}{ }^{2-}+9 \mathrm{H}^{+} \rightarrow 12 \mathrm{CO}_{2} \\
& +7 \mathrm{HS}^{-}+8 \mathrm{H}_{2} \mathrm{O},
\end{aligned}
$$

and a fermenting bacterium converted sorbate mainly to about equal amounts of acetate and butyrate:

$$
\begin{aligned}
& \mathrm{C}_{6} \mathrm{H}_{7} \mathrm{O}_{2}^{-}+2 \mathrm{H}_{2} \mathrm{O} \rightarrow \mathrm{C}_{2} \mathrm{H}_{3} \mathrm{O}_{3}^{-} \\
& +\mathrm{C}_{4} \mathrm{H}_{7} \mathrm{O}_{2}^{-}+\mathrm{H}^{+} .
\end{aligned}
$$

Both bacteria isolated tolerated this bacteriostatic agent only up to concentrations around $10 \mathrm{mM}$ (= $1.12 \mathrm{~g} / \mathrm{l})$ without significant impairment of energy metabolism; higher concentrations caused significant decreases in cell yields. Obviously, sorbate is a rather potent agent also against these sorbatedegrading bacteria.

\section{Biochemistry of sorbate degradation}

The double bonds in the sorbate molecule are localized in a pattern well suited for degradation through classical $\beta$-oxidation. After binding to coenzyme $A$, hydration and further oxidation to acetyl-CoA units should not pose any basic difficulties. However, it cannot be ruled out at present that hydration occurs with the non-activated acid, and that the $\beta$-hydroxy acid is activated afterwards. The 
sulfate-reducing bacterium oxidizes the three acetyl residues to $\mathrm{CO}_{2}$, as most acetate-oxidizing sulfate reducers do (Widdel 1988), through the noncyclic carbon monoxide pathway (Schauder et al. 1986) as presence of this enzyme and lack of 2oxoglutarate synthase activity indicate.

With the fermenting bacterium AmSo1, the initial reactions are probably the same as discussed above, and the unsaturated acid derivative is subsequently dismutated to acetate and butyrate (Fig. 6), analogous to crotonate dismutation by Ilyobacter polytropus (Stieb \& Schink 1984) or Ilyobacter delafieldii (Janssen \& Harfoot 1990), or to crotonate or sorbate dismutation by Syntrophomonas wolfei (Beaty \& McInerney 1990). An unexpected finding was the formation of pentanone- 2 and isopentanone-2 (3-methyl-2-butanone) as byproducts, especially at enhanced substrate concentrations. Formation of pentanone- 2 can be easily explained through a sidepass of sorbate dismutation (Fig. 6): Reduction of the intermediate 3-oxy-4hexenoic acid and subsequent decarboxylation leads directly to this product:

$$
\begin{aligned}
& \mathrm{C}_{6} \mathrm{H}_{7} \mathrm{O}_{2}^{-}+\mathrm{H}^{+}+\mathrm{H}_{2} \mathrm{O} \rightarrow \mathrm{C}_{5} \mathrm{H}_{10} \mathrm{O}+\mathrm{CO}_{2} \\
& \Delta \mathrm{G}^{\circ \prime} \approx-75 \mathrm{~kJ} \cdot \mathrm{mol}^{-1}
\end{aligned}
$$

This transformation is probably not coupled to energy conservation, and can be understood as a side reaction occurring especially when the cellular energy metabolism is partly uncoupled, e.g. by sorbate at enhanced concentrations.

Formation of small amounts of isopentanone-2 together with pentanone- 2 can be understood as an isomerization of the butyryl constituent which would be released by thiolytic cleavage of 3-oxohexanoyl-CoA. Butyrate-isobutyrate and reverse isomerisation have been observed in anaerobic enrichment cultures from sludge samples (Tholozan et al. 1988) and a pure culture of a recently isolated strict anaerobe (Matthies \& Schink 1991). The reaction is catalyzed by a coenzyme $B_{12}$-dependent acyl-CoA mutase enzyme (Matthies \& Schink 1991). Excretion of significant amounts of isopentanone together with $n$-pentanone indicates that the various activated fatty acid residues involved in

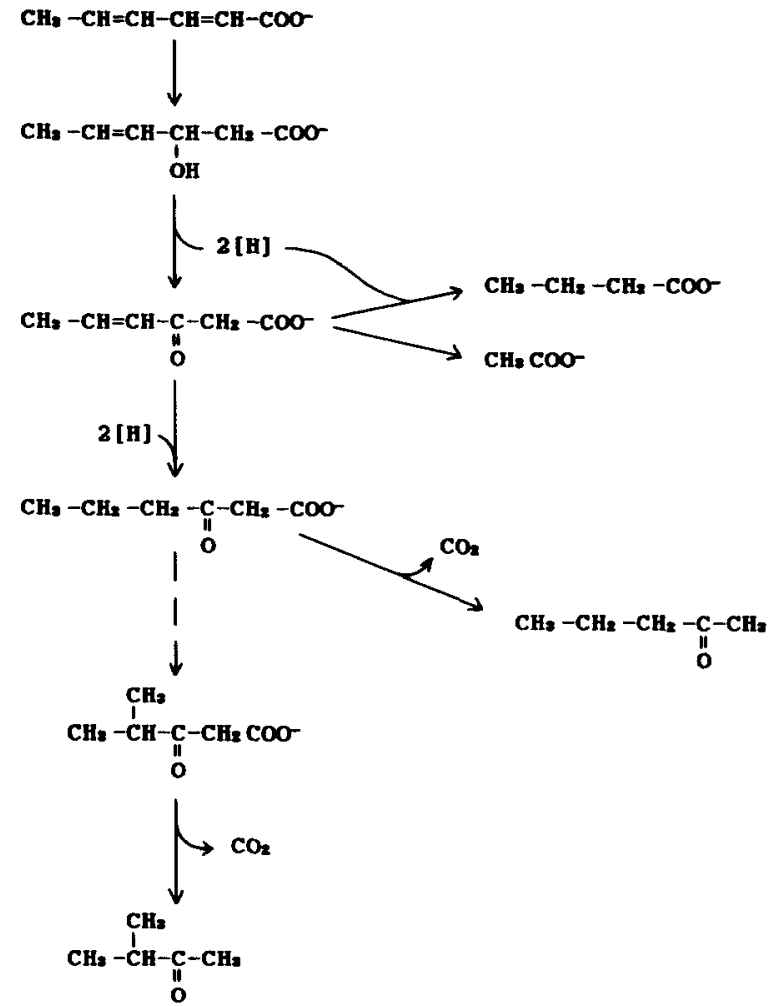

Fig. 6. Hypothetical pathway of sorbate degradation by strain AmSo1. All conversions of acid residues occur probably with the respective coenzyme $\mathbf{A}$ derivatives.

sorbate degradation exchange actively, probably via CoA transferases.

\section{Taxonomy}

On the basis of its morphology and the pathway of acetate oxidation, strain WoSo1 can be affiliated with Desulfoarculus (formerly Desulfovibrio) baarsii (Widdel \& Bak 1991). Also the capacity to utilize numerous fatty acids agrees with this affiliation. However, strain WoSo1 degraded also alcohols, lactate and puryvate, and differs with this from $D$. baarsii. The type strain of $D$. baarsii was tested for growth with sorbic acid, too, and good growth was observed. Therefore, strain WoSo1 should be affiliated with $D$. baarsii.

Strain AmSol is less easy to affiliate. As a Gramnegative strict anaerobe, it belongs to the family 
Bacteroidaceae. Physiologically, it resembles most Ilyobacter polytropus and I. delafieldii, however, the guanine-plus-cytosine content of these species (29-32\%) are too low to assign the new isolate to this genus. Strain AmSo1 differs from the also sorbate-dismutating Syntrophomonas wolfei (Beaty \& McInerney 1990) by its inability to oxidize saturated fatty acids in syntrophic cooperation with methanogens. Final taxonomic assignment of this strain will be postponed until more data on its relationship to members of other taxa are at hand.

\section{Acknowledgements}

We thank Dr. F. Bak and K.-J. Maier for stimulative discussions, Prof. Dr. F. Widdel for a culture of Desulfoarculus baarsii. strain 1st1, and Dr. Harald Platen for assistance in gas chromatographic identification of pentanones.

\section{References}

Bayer H \& Walter W (1988) Lehrbuch der organischen Chemie, 21 ed. Hirzel Verlag, Stuttgart

Beaty PS \& McInerney MJ (1990) Nutritional features of Syntrophomonas wolfei. Appl. Environ. Microbiol. 56: 32233224

Borst-Pauwels GWFH \& Jager S (1969) Inhibition of phosphate and arsenate uptake in yeast by monoiodoacetate, fluoride, 2,4-dinitrophenol and acetate. Biochim. Biophys. Acta 172: 399-406

Bradford M (1976) A rapid and sensitive method for the quantification of microgram quantities of protein utilizing the principle of protein-dye binding. Anal. Biochem. 72: 248-254

Brandis-Heep A, Gebhardt NA, Thauer RK, Widdel F, Pfennig N (1983) Anaerobic acetate oxidation to $\mathrm{CO}_{2}$ by Des. ulfobacter postgatei. 1. Demonstration of all enzymes required for the operation of the citric acid cycle. Arch. Microbiol. 136: 222-229

De Ley J (1970) Reexamination of the association between melting point, buoyant density and the chemical base composition of deoxyribonucleic acid. J. Bacteriol. 101: 738-754

Diekert GB \& Thauer RK (1978) Carbon monoxide oxidation by Clostridium thermoaceticum and Clostridium formicoacetium. J. Bacteriol. 136: 597-606

Eklund T (1985) The effect of sorbic acid and esters of $p$ hydroxybenzoic acid on the protonmotive force in Escherichia coli membrane vesicles. J. Gen. Microbiol. 131: 73-76
Fulgraff G (1989) Lebensmitteltoxikologie, 1 ed. Ulmer Verlag, Stuttgart

Freese E, Sheu CW \& Galliers E (1973) Function of lipophilic acids as antimicrobial food additives. Nature 241: 321-325

Janssen PH \& Harfoot CG (1990) Ilyobacter delafieldii sp. nov., a metabolically restricted anaerobic bacterium fermenting PHB. Arch. Microbiol. 154: 253-259

Magee CM, Rodeheaver G, Edgerton MT \& Edlich RF (1975) A more reliable Gram staining technic for diagnosis of surgical infections. Am. J. Surgery 130: 341-346

Marmur J (1961) A procedure for the isolation of deoxyribonucleic acid from microorganisms. J. Mol. Biol. 3: 208-218

Matthies C \& Schink B (1991) Reciprocal isomerization of butyrate and isobutyrate through a coenzyme $\mathrm{B}_{12}$-dependent butyryl-CoA : isobutyrylCoA mutase in cell-free extracts of strain WoGl3. Arch. Microbiol. (submitted)

Pfennig N (1978) Rhodocyclus purpureus gen. nov. and sp. nov., a ring-shaped, vitamin $B_{12}$-requiring member of the family Rhodospirillaceae. Int. J. System Bacteriol. 23: 283288

Ronning IE \& Frank HA (1987) Growth inhibition of putrefactive anaerobe 3679 caused by stringent-type response induced by protonophoric activity of sorbic acid. Appl. Environ. Microbiol. 53: 1020-1027

- (1989) Morphological changes in putrefactive anaerobe 3679 (Clostridium sporogenes) induced by sorbate, hydrochloric acid and nitrite. Can. J. Microbiol. 35: 388-398

Russel AD \& Gould GW (1988) Resistence of Enterobacteriaceae to preservatives and disinfectants. J. Appl. Bacteriol. Symp. Suppl: $167 \mathrm{~S}-195 \mathrm{~S}$

Salmond CV, Knoll RG \& Booth JR (1984) The effect of food preservatives on the $\mathrm{pH}$ homeostatis in Escherichia coli. $\mathrm{J}$. Gen. Microbiol. 130: 2845-2850

Schauder R, Eikmanns B, Thauer RK, Widdel F \& Fuchs G (1986) Acetate oxidation to $\mathrm{CO}_{2}$ in anaerobic bacteria via a novel pathway not involving reactions of the citric acid cycle. Arch. Microbiol. 145: 162-172

Schink B \& Pfennig N (1982) Fermentation of trihydroxybenzenes by Pelobacter acidigallici gen. nov. sp. nov., a new strictly anaerobic, non-sporeforming bacterium. Arch. Microbiol. 133: 195-201

Schnell S \& Schink B (1991) Anaerobic aniline degradation via reductive deamination of 4-aminobenzoyl-CoA in Desulfobacterium anilini. Arch. Microbiol. 155: 183-190

Stieb M \& Schink B (1984) A new 3-hydroxybutyrate fermenting anaerobe, Ilyobacter polytropus gen. nov. sp. nov., possessing various fermentation pathways. Arch. Microbiol. 140: 139-146

Tholozan J-L, Samain E \& J-P Grivet (1988) Isomerization between $n$-butyrate and isobutyrate in enrichment cultures. FEMS Microbiol. Ecol. 53: 187-191

Widdel F (1988) Microbiology and ecology of sulfate- and sulfur-reducing bacteria. In: Zehnder AJB (Ed) Biology of Anaerobic Microorganisms (pp 469-639). Wiley \& Sons, New York

Widdel F \& Bak F (1991) Gram-negative mesophilic sulfate- 
reducing bacteria. In: Balows $A$, Trüper $H G$, Dworkin $M$, Harder W \& Schleifer KH (Eds) The Prokaryotes, 2nd edition. Springer New York (in press)

Widdel F \& Pfennig N (1981) Studies on dissimilatory sulfatereducing bacteria that decompose fatty acids. I. Isolation of new sulfate-reducing bacteria enriched with acetate from sa- line environments. Description of Desulfobacter postgatei gen. nov. sp. nov. Arch. Microbiol. 134: 286-294

Widdel F, Kohring GW \& Mayer F (1983) Studies on dissimilatory sulfate-reducing bacteria that decompose fatty acids. III. Characterization of the filamentous gliding Desulfonema limicola gen. nov. sp. nov., and Desulfonema magnum sp. nov. Arch. Microbiol. 134: 286-294 